\title{
Information System Design for Calculating the Reliability of Electricity Distribution System in Pekalongan Substation Based on Android OS
}

\author{
Salman Muntaqo Aprilian ${ }^{1}$, Faaris Mujaahid ${ }^{* 1,2}$, Ramadoni Syahputra ${ }^{1}$, Karisma Trinanda Putra ${ }^{1,3}$, \\ Widyasmoro $^{1}$ \\ ${ }^{1}$ Department of Electrical Engineering, Faculty of Engineering, Universitas Muhammadiyah Yogyakarta, Indonesia \\ ${ }^{2}$ Dept. of Aeronautics \& Astronautics, National Cheng Kung University, No.1 Univ. Rd., Tainan, Taiwan \\ ${ }^{3}$ College of Information and Electrical Engineering, Asia University Liufeng Road 500, Wufeng District, Taichung City, \\ Taiwan 41354 \\ *Corresponding author, e-mail: f.mujaahid@umy.ac.id
}

\begin{abstract}
Reliability of distribution networks is a factor that greatly affects customers as consumers of electricity. Analyzing and calculating the reliability of distribution networks are determined by the reliability index including SAIFI, SAIDI, CAIDI, and ASAI. On the other hand, smartphone technology is growing rapidly with a variety of applications to help simplify and accelerate human work in several fields of work. This paper delivers the design of an Android-phone-based analytic tool for distribution system reliability index measurement by developing it on Android application software. This application is named KALINDA, stands for Kalkulator Indeks Keandalan (Reliability Index Calculator), and created by using Android Studio IDE. We compare the data result between KALINDA calculations and manual calculations. The results obtained from the KALINDA application are declared to be valid accurate.
\end{abstract}

Keywords: Reliability Index, user interface, Android Studio, distribution networks

\section{Introduction}

Electric power is an energy that in this modern era is needed by the people in carrying out their daily activities. Electricity shortage is a problem because it will disrupt human activities, because electricity is already included in primary needs. The supply of electrical energy is carried out by an electric power system which includes a generation system, transmission system and distribution system. To guarantee the continuity of electrical energy services, a high level of reliability is required for all three elements of the electric power system. Of these three systems, the system that is closest to the load or the customer is the distribution system so that the reliability of this system will directly impact the burden or the customer. Disturbances in the generator system and transmission system can result in blackouts to the customer, but the effect on the customer is smaller than interference with the distribution system.
The increasing demand for electricity supply continues to increase from year to year. The development of electricity supply demand must be accompanied by an increase in production from the principal of electricity generation accompanied by an increase in infrastructure. It is hoped that the distribution of electrical energy to customers can be channeled with good quality distribution standards. The distribution network has a vital role to ensure the quality of the distribution of electrical energy in accordance with established standards. Distribution quality can be measured through a reliability index based on national and international standards. Analysis of the reliability of the power distribution system can be done by looking at the frequency of outages and outages experienced by each load connected by the system. The reliability of the distribution system is defined by the ability of the components of the distribution system to perform its functions properly in the conditions and predetermined time periods, in this case the period stipulated by the SPLN (Standard PLN) is one year 
for one period. SPLN is list of technical standards issued by PLN, Indonesian state-owned electricity company [1]. To understand the reliability of a feeder, there must be a standard that can be a benchmark called the reliability index. It is a benchmark number whose function is to weigh the service that is served from a feeder whether it meets the applicable standards or not. Among the indices referred to include SAIFI (System Average Interruption Frequency Index), SAIDI (System Average Interruption Frequency Index), CAIDI (Customer Average Interruption Frequency Index), and ASAI (Average Service Availability Index) [2].

On the other hand, technology is developing rapidly, especially information and telecommunications technology. Smartphone technology in this era is supported by various applications that are designed and made to facilitate and accelerate human activities or work. Smartphone embeds various types of operating systems used, e.g. Android, iOS, Windows, Blackberry, and Symbian. But the facts in the field state that almost $73 \%$ of smartphone users use this type of Android operating system. Some application developers who are often referred to as google developers also majority choose Android because of its ease in design, development, as well as fast and simple updates [3].

Therefore, the use of smartphones in the electricity sector can benefit the calculation process that can be done anytime, anywhere. Therefore, the researchers plan to build an application for calculating the value of the reliability of the Android-based electric power system which can later be used by operators of the electricity supply distribution system in the country of Indonesia i.e., PLN in particular and ordinary people in general.

\section{Related Work}

Several previous studies conducted a study on the design of a $20 \mathrm{kV}$ distribution system reliability software. The results of this study are an average program error of $0 \%$ using the section technique [4]. The reliability index of the feeder distribution system in the tested area is 5.065880003 times per year for SAIFI and this is not yet reliable because it exceeds the PLN limit which is 3.2 times per customer annually. While the other two indices, namely SAIDI 17.179399999 hours per customer annually and CAIDI 3.035873328 hours per year are included in the reliable category because they do not exceed the PLN provision which is 21 hours per customer annually and 6.5625 hours per year.
In another study, it was explained that the Monte Carlo technique is the most powerful and efficient method for evaluating the reliability of distribution networks [5]. This research relies on the Monte Carlo Simulation code in MATLAB. The results tested are effective software and serve as a tool that can be used in evaluating the reliability of distribution feeders.

In terms of reliability analysis and distribution losses in the regional of basis, for example in Yogyakarta province, Khaidir Ali et al and Slamet Suripto explain in their work how SAIDI-SAIFI parameters show the reliability of the Gejayan substation compared to the national standard [6] and technical calculation of distribution network losses on Bantul feeders [7].

\section{Methodology}

\section{III.1. Distribution System Reliability}

The reliability of the distribution system is an index of service level divided by availability of electricity supply coming from the distribution system to consumers. The reliability value can be measured by how often the system has experienced a blackout, how long the power outage took place, and how quickly the time used to restore the condition of the power outage that occurs is recovered. Several reliability indexes are used in the evaluation.

SAIFI index contains information about the reliability of the distribution system in the form of the average number of outages per customer.

$$
S A I F I=\frac{\lambda i . N i}{N t}
$$

where:

$\lambda \mathrm{i}=$ Frequency of Feeder Outage $\mathrm{i}$

$\mathrm{Ni}=$ Number of Customers in Feeder $\mathrm{i}$

$\mathrm{Nt}=$ Total Number of Customers

SAIDI index shares information about the reliability of the distribution system in the form of the duration or length of time an average blackout is felt by consumers.

$$
S A I D I=\frac{U i . N i}{N t}
$$

where:

$\mathrm{Ui}=$ Duration of Feeder Outage I, in hour

$\mathrm{Ni}=$ Number of Customers in Feeder $\mathrm{i}$

$\mathrm{Nt}=$ Total Number of Customers

CAIDI (Customer Average Interruption Duration 
Index) is the average value of the duration of consumer disturbances each year.

$$
\text { CAIDI }=\text { SAIDI / SAIFI }
$$

ASAI index provides information on the level of availability of electricity services received by consumers.

$$
A S A I=\frac{8760-S A I D I}{8760} \times 100
$$

where 8760 is the total hours in one year.

\section{III.2. Android Studio}

Android Studio is a software or application program with an integrated development environment or better known as the Integrated Development Environment (IDE) launched by Google platform that is useful for developing, designing, and creating application programs that are specific to mobile devices with the Android operating system. The main tools used in this study are a calculator, Android Studio Software, and mobile phones with the Android operating system. Then the materials needed are the reliability index formula, reliability index data based on the Pekalongan City District PLN, SPLN, and IEEE, the number of customers per feeder, frequency of blackouts for each feeder, and duration of outages of each feeder in the Pekalongan City District distribution system. The research location is at PT. PLN UPJ Pekalongan, Jalan Manggis No.2 Sampangan, East Pekalongan, Pekalongan City, Central Java 51126.

KALINDA is the name of an Android application designed by the authors. The comparison is carried out in order to check whether the data from the same source will be the same or not to determine whether the data from the manual calculation is valid and the KALINDA calculation results.

\section{Results}

The results shown are the application of calculating the reliability of the electrical distribution system, which is named KALINDA. The application's flowchart is shown in Figure 1 in bilingual. When the user opens KALINDA, boarding and splash screen are displayed. Followed by home screen. From the home screen, the user may choose whether he/she wants to calculate SAIFI. SAIDI, CAIDI, and and ASAI by entering the variables or to look first the manual guides.

Results page are displayed in Figure 2 and Figure 3. Unfortunately, KALINDA is still in Bahasa Indonesia, it should have English version for the next version. In Figure 2, user needs to provide three inputs for every feeder. There are 12 feeders in Figure 2, hence in total there are 12 variables in each column to fill in, which are Interruption frequency, Interruption duration, and Number of customers, respectively. Use Add (TAMBAH) button to create new line for the new feeder. When all the variables are entered, the user may click Calculate (HITUNG) to get the value of SAIFI, SAIDI, CAIDI, and ASAI for each feeder. These results are as shown in Figure 3. Table I shows the exported data in Excel format.

Based on Table II, the results of the SAIFI and SAIDI index values on all feeders in the Pekalongan City District distribution system are below the Pekalongan City District PLN standards of 3.62 (times per customers per year) and 9.77 (hours per customers per year) and SPLN standards of 3.2 (times per customer per year) and 21.09 (hour per customer per year). This means that the results of each SAIFI and SAIDI index do not exceed the limits set by the two standards mentioned above. Therefore, each feeder that serves the electricity needs in the City of Pekalongan is categorized reliable according to these two kinds of standards.

Table III shows that the majority of each feeder in the Pekalongan City District distribution system was declared reliable except for the three feeders namely PKL02, PKL08, PKL15 feeders. The three feeders are stated to be of less reliable status because of the same thing, namely the CAIDI index value that has exceeded the standard limits set by the IEEE, which is 1.47 hours in average of each interruption per year. While it can be seen in the data feeder PKL02 CAIDI value shows the number 1,604 hours in average of each interruption per year, the feeder PKL08 shows the number 1.49 hours in average of each interruption per year, the PKL15 feeder shows the number 3.19 hours in average of each interruption per year. Therefore, based on IEEE standards, the declared reliable feeders are PKL01, PKL04, PKL06, PKL07, PKL09, PKL10, PKL11, PKL12, PKL14 because the SAIFI, SAIDI, CAIDI index values do not exceed the limits and ASAI index values are not less than the limit determined by the IEEE. Whereas the other feeders, the three feeders mentioned earlier, are in the less reliable category. 


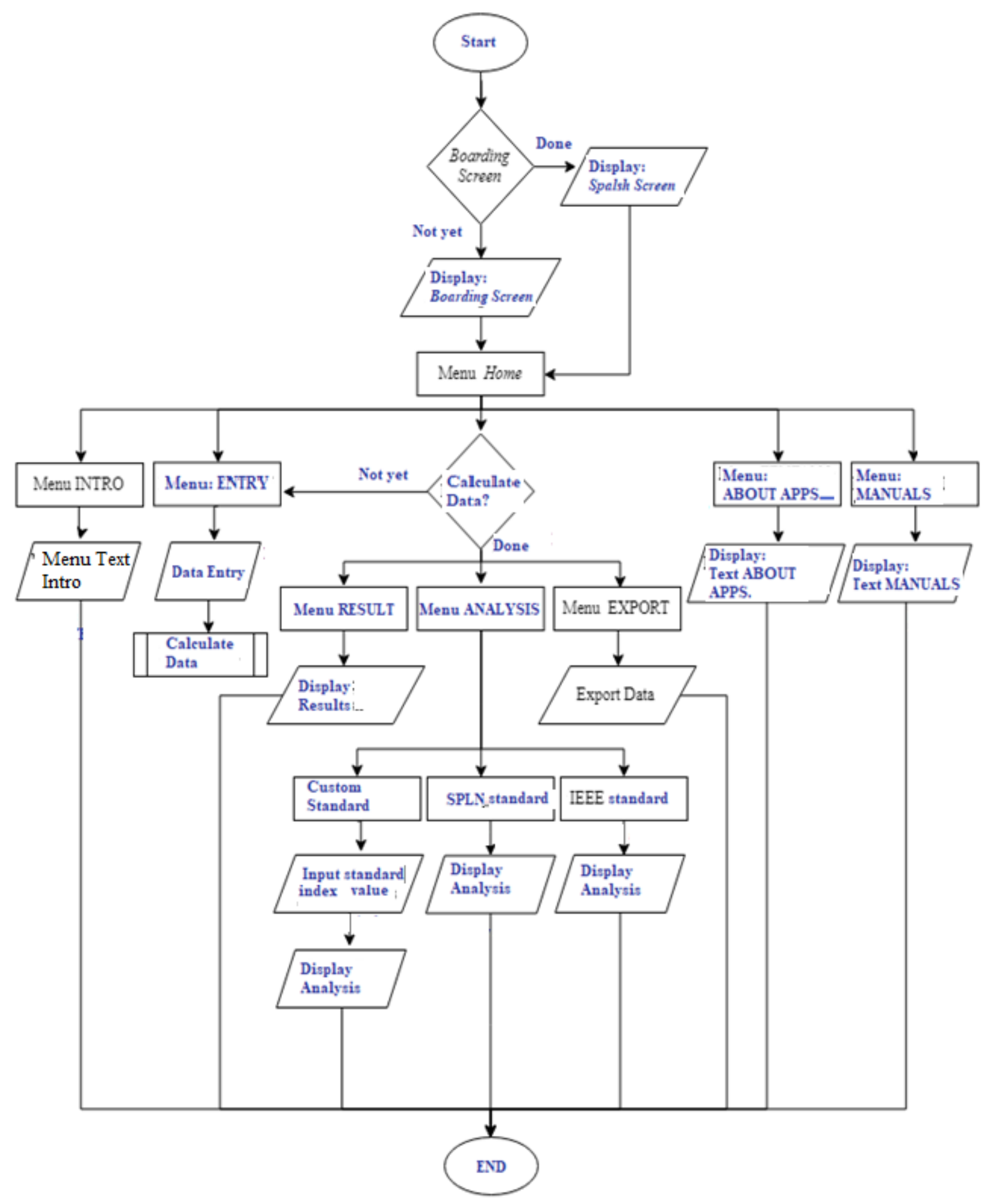

Fig 1. Design of KALINDA system flowchart with English translation 


\begin{tabular}{ccccc}
$\leftarrow$ & DATA ENTRY & & \\
\hline No. & $\begin{array}{c}\text { Nama } \\
\text { Feeder }\end{array}$ & $\begin{array}{c}\text { Frekuensi } \\
\text { Gangguan }\end{array}$ & $\begin{array}{c}\text { Durasi } \\
\text { Gangguan } \\
\text { jam) }\end{array}$ & $\begin{array}{c}\text { Jumlah } \\
\text { Pelanggan } \\
\text { Fumber of }\end{array}$ \\
\hline & $\begin{array}{c}\text { Feeder } \\
\text { Name }\end{array}$ & $\begin{array}{c}\text { Interruption } \\
\text { Frequency }\end{array}$ & $\begin{array}{c}\text { Interruption } \\
\text { Duration (hour) }\end{array}$ & $\begin{array}{c}\text { Nustomer } \\
\text { Cust }\end{array}$ \\
\hline 1 & PKL01 & 3 & 1.883 & 19432 \\
2 & PKL02 & 2 & 3.2 & 9958 \\
3 & PKL04 & 4 & 2.216 & 17510 \\
4 & PKL06 & 3 & 1.26 & 22976 \\
5 & PKL07 & 3 & 1.183 & 32546 \\
6 & PKL08 & 3 & 4.5 & 6414 \\
7 & PKL09 & 0 & 0.0 & 23111 \\
8 & PKL10 & 1 & 1.03 & 31825 \\
9 & PKL11 & 4 & 4.2 & 1235 \\
10 & PKL12 & 3 & 2.3 & 25155 \\
11 & PKL14 & 2 & 2.15 & 4858 \\
12 & PKL15 & 2 & 6.2 & 2119 \\
& & & & \\
\hline
\end{tabular}

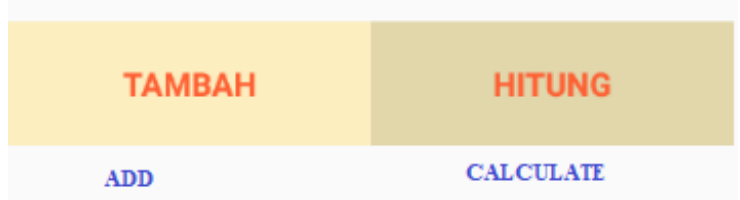

Fig 2. Data entry page (KALINDA GUI)

\begin{tabular}{cccccc}
$\leftarrow$ & RESULTS \\
\hline No. & $\begin{array}{c}\text { Nama } \\
\text { Feeder }\end{array}$ & $\begin{array}{c}\text { Nilai } \\
\text { SAlFI } \\
(\mathrm{K} / \mathrm{p} / \mathrm{t})\end{array}$ & $\begin{array}{c}\text { Nilai } \\
\text { SAIII } \\
(\mathrm{j} / \mathrm{p} / \mathrm{t})\end{array}$ & $\begin{array}{c}\text { Nilai } \\
\text { CADI } \\
(\mathrm{J} / \mathrm{k} / \mathrm{t})\end{array}$ & $\begin{array}{c}\text { Nilai } \\
\text { ASAI } \\
(\%)\end{array}$ \\
\hline 1 & PKL01 & 0,099 & 0,062 & 0,626 & 99.99 \\
2 & PKL02 & 0,034 & 0,054 & 1,588 & 99.99 \\
3 & PKL04 & 0,118 & 0,066 & 0,559 & 99.99 \\
4 & PKL06 & 0,117 & 0,049 & 0,419 & 99.99 \\
5 & PKL07 & 0,165 & 0,065 & 0,394 & 99.99 \\
6 & PKL08 & 0,033 & 0,049 & 1,485 & 99.99 \\
7 & PKL09 & 0 & 0 & 0 & 100.0 \\
8 & PKL10 & 0,054 & 0,055 & 1,019 & 99.99
\end{tabular}

Fig 3. Result page (KALINDA GUI)

TABLE I.

Exported result, more details in number fractions

\begin{tabular}{llllr}
\hline \multicolumn{1}{c}{ Feeder } & SAIFI & \multicolumn{1}{c}{ SAIDI } & \multicolumn{1}{c}{ CAIDI } & ASAI \\
\hline PKL01 & 0.099 & 0.062 & 0.626263 & 99.9993 \\
PKL02 & 0.034 & 0.054 & 1.58824 & 99.9994 \\
PKL04 & 0.118 & 0.066 & 0.559322 & 99.9992 \\
PKL06 & 0.117 & 0.049 & 0.418803 & 99.9994
\end{tabular}

\begin{tabular}{lllll} 
PKL07 & 0.165 & 0.065 & 0.393939 & 99.9993 \\
PKL08 & 0.033 & 0.049 & 1.48485 & 99.9994 \\
PKL09 & 0 & 0 & 0 & 100 \\
PKL10 & 0.054 & 0.055 & 1.01852 & 99.9994 \\
PKL11 & 0.008 & 0.009 & 1.125 & 99.9999 \\
PKL12 & 0.128 & 0.098 & 0.765625 & 99.9989 \\
PKL14 & 0.016 & 0.018 & 1.125 & 99.9998 \\
PKL15 & 0.007 & 0.022 & 3.14286 & 99.9997 \\
\hline
\end{tabular}

TABLE II.

Analysis using PLN City District and SPLN standard

\begin{tabular}{|c|c|c|c|c|c|c|}
\hline \multirow[b]{2}{*}{ Feeder } & \multicolumn{2}{|c|}{ KALINDA } & \multicolumn{2}{|c|}{$\begin{array}{c}\text { PLN } \\
\text { Pekalongan } \\
\end{array}$} & \multicolumn{2}{|c|}{ SPLN } \\
\hline & $\begin{array}{c}\text { SAI } \\
\text { FI }\end{array}$ & $\begin{array}{c}\text { SAI } \\
\text { DI }\end{array}$ & $\begin{array}{c}\text { SAIFI } \\
3.62 \\
\mathbf{k} / \mathbf{p} / \mathbf{t}\end{array}$ & $\begin{array}{c}\text { SAIDI } \\
9.77 \\
\mathrm{j} / \mathbf{p} / \mathbf{t}\end{array}$ & $\begin{array}{c}\text { SAIFI } \\
3.2 \\
\mathbf{k} / \mathbf{p} / \mathbf{t}\end{array}$ & $\begin{array}{c}\text { SAIDI } \\
21.09 \\
\text { j/p/t }\end{array}$ \\
\hline PKL01 & 0.295 & 0.185 & $\checkmark$ & $\checkmark$ & $\checkmark$ & $\checkmark$ \\
\hline PKL02 & 0.101 & 0.162 & $\checkmark$ & $\checkmark$ & $\checkmark$ & $\checkmark$ \\
\hline PKL04 & 0.355 & 0.197 & $\checkmark$ & $\checkmark$ & $\checkmark$ & $\checkmark$ \\
\hline PKL06 & 0.349 & 0.147 & $\checkmark$ & $\checkmark$ & $\checkmark$ & $\checkmark$ \\
\hline PKL07 & 0.495 & 0.195 & $\checkmark$ & $\checkmark$ & $\checkmark$ & $\checkmark$ \\
\hline PKL08 & 0.097 & 0.146 & $\checkmark$ & $\checkmark$ & $\checkmark$ & $\checkmark$ \\
\hline PKL09 & 0 & 0 & $\checkmark$ & $\checkmark$ & $\checkmark$ & $\checkmark$ \\
\hline PKL10 & 0.161 & 0.166 & $\checkmark$ & $\checkmark$ & $\checkmark$ & $\checkmark$ \\
\hline PKL11 & 0.025 & 0.026 & $\checkmark$ & $\checkmark$ & $\checkmark$ & $\checkmark$ \\
\hline PKL12 & 0.383 & 0.29 & $\checkmark$ & $\checkmark$ & $\checkmark$ & $\checkmark$ \\
\hline PKL14 & 0.049 & 0.053 & $\checkmark$ & $\checkmark$ & $\checkmark$ & $\checkmark$ \\
\hline PKL15 & 0.021 & 0.067 & $\checkmark$ & $\checkmark$ & $\checkmark$ & $\checkmark$ \\
\hline
\end{tabular}

TABLE III.

Analysis using IEEE standard

\begin{tabular}{|c|c|c|c|c|c|c|c|c|}
\hline \multirow[b]{2}{*}{ Feeder } & \multicolumn{4}{|c|}{ KALINDA } & \multicolumn{4}{|c|}{ IEEE } \\
\hline & $\begin{array}{c}\text { SAI } \\
\text { FI }\end{array}$ & $\begin{array}{c}\text { SAI } \\
\text { DI }\end{array}$ & $\begin{array}{c}\text { CAI } \\
\text { DI }\end{array}$ & $\begin{array}{l}\text { AS } \\
\text { AI }\end{array}$ & $\begin{array}{c}\text { SAI } \\
\text { FI } \\
<1.45 \\
\text { k/p/t }\end{array}$ & $\begin{array}{c}\text { SAI } \\
\text { DI } \\
<2.3 \\
\mathrm{j} / \mathrm{p} / \mathrm{t}\end{array}$ & $\begin{array}{c}\text { CAI } \\
\text { DI } \\
<1.47 \\
\text { j/k/t }\end{array}$ & $\begin{array}{c}\text { ASAI } \\
>99.92 \\
\%\end{array}$ \\
\hline PKL01 & 0.295 & 0.185 & 0.628 & 99.99 & $\checkmark$ & $\checkmark$ & $\checkmark$ & $\checkmark$ \\
\hline PKL02 & 0.101 & 0.162 & 1.604 & 99.99 & $\checkmark$ & $\checkmark$ & $x$ & $\checkmark$ \\
\hline PKL04 & 0.355 & 0.197 & 0.555 & 99.99 & $\checkmark$ & $\checkmark$ & $\checkmark$ & $\checkmark$ \\
\hline PKL06 & 0.349 & 0.147 & 0.42 & 99.99 & $\checkmark$ & $\checkmark$ & $\checkmark$ & $\checkmark$ \\
\hline PKL07 & 0.495 & 0.195 & 0.394 & 99.99 & $\checkmark$ & $\checkmark$ & $\checkmark$ & $\checkmark$ \\
\hline PKL08 & 0.097 & 0.146 & 1.49 & 99.99 & $\checkmark$ & $\checkmark$ & $x$ & $\checkmark$ \\
\hline PKL09 & 0 & 0 & 0 & 100 & $\checkmark$ & $\checkmark$ & $\checkmark$ & $\checkmark$ \\
\hline PKL10 & 0.161 & 0.166 & 1.031 & 99.99 & $\checkmark$ & $\checkmark$ & $\checkmark$ & $\checkmark$ \\
\hline PKL11 & 0.025 & 0.026 & 1.04 & 99.99 & $\checkmark$ & $\checkmark$ & $\checkmark$ & $\checkmark$ \\
\hline PKL12 & 0.383 & 0.29 & 0.765 & 99.99 & $\checkmark$ & $\checkmark$ & $\checkmark$ & $\checkmark$ \\
\hline PKL14 & 0.049 & 0.053 & 1.082 & 99.99 & $\checkmark$ & $\checkmark$ & $\checkmark$ & $\checkmark$ \\
\hline PKL15 & 0.021 & 0.067 & 3.19 & 99.99 & $\checkmark$ & $\checkmark$ & $x$ & $\checkmark$ \\
\hline
\end{tabular}




\section{Conclusion}

This calculation application called KALINDA (Reliability Index Calculator) can be used to calculate SAIFI, SAIDI, CAIDI, and ASAI indices with the results of calculations that have been compared and verified with manual calculations with accurate results. Based on the PLN District Pekalongan City standard, the work of the distribution network at each feeder in Pekalongan City is in accordance with the established standards namely the SAIFI index does not exceed 3.62 times per customer annually and the SAIDI index does not exceed 9.77 hours per customer annually.

Based on the SPLN standard No.68-2 of 1986, the distribution network work at each feeder in Pekalongan City is already reliable according to the established standards, namely the SAIFI index does not exceed 3.2 times per customer annually and the SAIDI index does not exceed 21.09 hours per customer annually [8]. Based on the IEEE standard, the work of the distribution network at each feeder at PLN District in Pekalongan City is already reliable according to the established standards, namely according to the SAIFI index, SAIDI, CAIDI not exceeding 1.45 times per customer annually, 2.3 hours per customer annually, 1.47 hours per interruption annually and ASAI more than $99.92 \%$. However, there are some feeders that are less reliable due to CAIDI values that exceed the specified limits, namely feeders PKL02, PKL08, PKL15 with a repective value of $1,604,1.49$, and 3.19 hours per interruption annually.

\section{Availability of data and materials}

All data including and source code are fully available upon request through corresponding email.

\section{References}

[1] Standard PLN. (1985).

[2] Pham, H. \& Wang, H. Springer Series in Reliability Engineering. Springer (2006). doi:10.1007/978-1-44714588-2.

[3] Di Nucci, D. et al. Software-based energy profiling of Android apps: Simple, efficient and reliable? in SANER 2017 - 24th IEEE International Conference on Software Analysis, Evolution, and Reengineering (2017). doi:10.1109/SANER.2017.7884613.

[4] HAQ, M. N. Analisis Keandalan Sistem Distribusi $20 \mathrm{KV}$ di Gardu Induk Batang. (Universitas Muhammadiyah Yogyakarta, 2016).

[5] Aljohani, T. M. \& Beshir, M. J. Matlab Code to Assess the Reliability of the Smart Power Distribution System Using Monte Carlo Simulation. J. Power Energy Eng. (2017) doi:10.4236/jpee.2017.58003.
[6] Ali, K., Wiyagi, R. O. \& Syahputra, R. Reliability Analysis of Power Distribution System. J. Electr. Technol. UMY 1, (2017) doi:10.18196/jet.1210.

[7] Suripto, S. Calculation of $20 \mathrm{kV}$ Distribution Network Energy Losses and Minimizing Effort Using Network Reconfiguration in Region of PT PLN (Persero) UPJ Bantul. J. Electr. Technol. UMY (2017) doi:10.18196/jet.1210.

[8] Standard PLN 68-2. (1986).

\section{Authors' information}

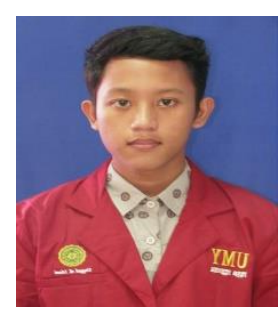

Salman Muntaqo Aprilian was a bachelor student of Electrical Engineering, Faculty of Engineering, Universitas Muhammadiyah Yogyakarta, and finished his study in 2019.

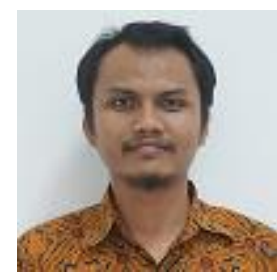

Faaris Mujaahid Hold a bachelor degree in 2010 from Electrical and Electronics Engineering Department, Saxion University of Applied Sciences, the Netherlands. He received a master degree in Sustainable Energy Technologies in 2016 from University of Southampton, UK. ing. Faaris Mujaahid, M.Sc is currently a lecturer in the Department of Electrical Engineering, Faculty of Engineering, Universitas Muhammadiyah Yogyakarta, Indonesia. His main research interest is in LabVIEW and renewable energy (mainly in solar cell material and fabrication technologies).

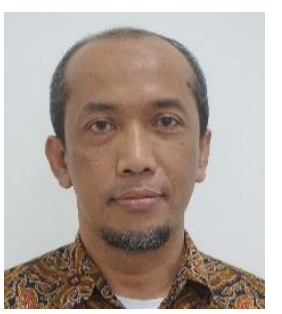

Ramadoni Syahputra received B.Sc. degree from Institut Teknologi Medan in 1998, M.Eng. degree from Department of Electrical Engineering, Universitas Gadjah Mada, Yogyakarta, Indonesia in 2002, and Ph.D degree at the Department of Electrical Engineering, Faculty of Industrial Technology, Institut Teknologi Sepuluh Nopember, Surabaya, Indonesia in 2015. Dr. Ramadoni Syahputra is a Lecturer in Department of Electrical Engineering, Faculty of Engineering, Universitas Muhammadiyah Yogyakarta, Indonesia. His research interests are in computational of power system, artificial intelligence in power system, power system control, the application of fuzzy logic in power system, optimization, distributed energy resources, and renewable energy.

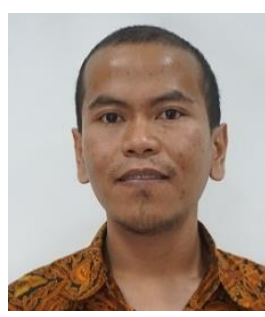

Karisma T. Putra born in Bondowoso on June 19, 1990. Graduated from elementary to senior high school in Bondowoso until 2008. Studied bachelor degree program in Surabaya, precisely in Electronics Engineering Polytechnic Institute of Surabaya (EEPIS) until 2012. He got scholarship program to continue master degree in Institut Teknologi Sepuluh Nopember (ITS) Surabaya. Now, he is doing a doctorate degree in Asia University Taiwan. Karisma is also a lecturer at 
Electrical Engineering Department, Faculty of Engineering, Universitas Muhammadiyah Yogyakarta. The main focus of research is the intelligent systems and controls. He engaged in joint research related to the development of food commodity tracking systems and integrated intelligent systems. He was involved in several competitions in developing smart devices. Pursue the field of electronics and software development since college. Mr. Putra joined in Indonesian's engineer union organization (PII) in 2016. Mr. Putra is also active in writing publications on IEEE society.

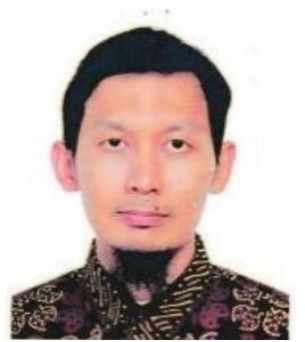

Widyasmoro obtained his B.Eng. in Electrical Engineering from Universitas Jenderal Soedirman, Indonesia in 2007. His Master study was done at 2009 at the Electrical Engineering, Asia University, Taiwan. $\mathrm{He}$ currently is a lecture in the Department of Electrical Engineering, Universitas Yogyakarta. 